\title{
A High-Throughput Screen of a Library of Therapeutics Identifies
}

\section{Substrates of P-glycoprotein}

Tobie D. Lee, Olivia W. Lee, Kyle R. Brimacombe, Lu Chen, Rajarshi Guha, Sabrina Lusvarghi,

Bethilehem G. Tebase, Carleen Klumpp-Thomas, Robert W. Robey, Suresh V. Ambudkar, Min

Shen, Michael M. Gottesman, Matthew D. Hall

National Center for Advancing Translational Sciences (T.D.L., O.W.L, K.R.B, L.C., R.G., C.K.-

L., M.S., M.D.H.) National Institutes of Health, Rockville MD and ${ }^{2}$ Laboratory of Cell Biology

(S.L., B.G.T., R.W.R, S.V.A., M.M.G.), National Cancer Institute, National Institutes of Health,

Bethesda, MD, U.S.A. 
Running title: High-throughput screen to identify P-gp substrates

Corresponding Author:

Matthew D. Hall, PhD

National Center for Advancing Translational Sciences

National Institutes of Health

9800 Medical Center Drive, Building B

Rockville, MD 20850

hallma@mail.nih.gov

Number of text pages: 28

Number of tables: 2

Figures: 6

References: 45

Number of words in the Abstract: 248

Introduction: 687

Discussion: 912

Non-standard abbreviations:

P-gp, P-glycoprotein; BBB, blood-brain barrier; HTS, high-throughput screen; ABCB1, ATPbinding cassette family member B1; ABCG2, ATP-binding cassette family member G2;

NCATS, National Center for Advancing Translational Science; NPC, NCATS Pharmaceutical Collection; MIPE, Mechanism Interrogation Plate; NPACT, NCATS Pharmacologically Active Chemical Toolbox; PhA, pheophorbide A; FTC, Fumitremorgin C; AUC, area under the curve; NAMPT, nicotinamide phosphoribosyltransferase; CDK, cyclin-dependent kinase; PI3K, phosphoinositide-3 kinase; mTOR, mammalian target of rapamycin; JAK, Janus kinase 


\begin{abstract}
The ATP-binding cassette transporter P-glycoprotein (P-gp) is known to limit brain penetration of many chemotherapy drugs. Although Food and Drug Administration guidelines require that potential interactions of investigational drugs with P-gp be explored, often this information does not enter into the literature. As such, we developed a high-throughput screen (HTS) to identify substrates of P-gp from a series of chemical libraries, testing a total of 10,804 compounds, most of which have known mechanisms of action. We used the CellTiter-Glo viability assay to test library compounds against parental KB-3-1 human cervical adenocarcinoma cells and the colchicine-selected sub-line KB-8-5-11 that over-expresses P-gp. KB-8-5-11 cells were also tested in the presence of a P-gp inhibitor (tariquidar) to assess reversability of transportermediated resistance. Of the tested compounds, a total of $90 \mathrm{P}$-gp substrates were identified including 55 newly identified P-gp substrates. Substrates were confirmed using an orthogonal killing assay against HEK-293 cells transfected with P-gp. We confirmed that AT7159 (cyclindependent kinase inhibitor); AT9283, (Janus kinase 2/3 inhibitor); ispinesib (kinesin spindle protein inhibitor); gedatolisib (PKI-587, phosphoinositide 3-kinase/mammalian target of rampamycin inhibitor); GSK-690693 (AKT inhibitor); and KW-2478 (heat shock protein 90 inhibitor) were substrates, and direct ATPase stimulation was assessed. ABCG2 was also found to confer high levels of resistance to AT9283, GSK-690693 and gedatolisib, while ispinesib, AT7519 and KW-2478 were weaker substrates. Combinations of P-gp substrates and inhibitors were assessed to demonstrate on-target synergistic cell killing. This data will be of use in determining understanding how chemotherapeutic agents will cross the blood-brain barrier.
\end{abstract}




\section{Introduction}

The ATP-binding cassette (ABC) transporters P-glycoprotein (P-gp, encoded by the $M D R 1$ gene and later renamed $A B C B 1$ ) and ABCG2 (or breast cancer resistance protein, encoded by the $A B C G 2$ gene) play major roles in limiting the oral bioavailability of compounds and preventing drug ingress at the blood-brain barrier (BBB) by keeping toxins, drugs, and other compounds out of the brain (Gottesman et al., 2016). Soon after its identification as a drug transporter, P-gp was found to be expressed in the small intestine and colon, liver, pancreas, and kidney (Thiebaut et al., 1987), and pharmacokinetic studies in mice deficient for one of the murine homologs of human $A B C B 1, M d r l a$ (renamed $A b c b 1 a$ ) demonstrated increased bioavailability of orally-administered taxol compared to wild-type mice (Sparreboom et al., 1997). Likewise, ABCG2 was detected in the small intestine and colon (Fetsch et al., 2006; Maliepaard et al., 2001) and the role of ABCG2 in limiting oral uptake of topotecan was confirmed in mice lacking $A b c g 2$ expression, the murine homolog of $A B C G 2$ (Basseville et al., 2016; Jonker et al., 2000).

In addition to being highly expressed in the gastrointestinal tract, in the brush border of renal proximal tubule cells and on the apical surface of hepatocytes (Fetsch et al., 2006; Huls et al., 2008; Thiebaut et al., 1987), both P-gp and ABCG2 are expressed at high levels on the apical side of capillary endothelial cells in the brain (Cooray et al., 2002; Cordon-Cardo et al., 1989; Thiebaut et al., 1987; Thiebaut et al., 1989). The protective role of P-gp was demonstrated in 1994 when Schinkel and colleagues found that deletion of Abcbla in mice resulted in acute sensitivity to the acaricide ivermectin due to a 90 -fold increase in brain penetration of the drug (Schinkel et al., 1994). Brain penetration of the P-gp substrate drug vinblastine was increased 20fold in Abcbla-deficient mice (Schinkel et al., 1994). Subsequent to the discovery of ABCG2, mice deficient in the two murine homologs of human ABCB1 $(A b c b 1 a / 1 b)$ and Abcg2 were generated. The murine models highlighted a compensatory and possibly a cooperative role for the two transporters at the BBB limiting the brain penetration of chemotherapeutic agents, in particular kinase inhibitors (Basseville et al., 2016). In a recent example, $24 \mathrm{~h}$ after mice were given an oral dose of the BCR-ABL kinase inhibitor ponatinib, mice lacking Abcg2 expression had a 2.2-fold increase in brain concentration compared to wild-type mice, while mice lacking $A b c b 1 a / 1 b$ had a 1.9-fold increase and mice lacking $A b c b 1 a / 1 b$ and $A b c g 2$ had a 25.5 -fold increase (Kort et al., 2017). The mouse studies highlight not only the protective and complementary role of the transporters at the BBB but also their importance in thwarting effective delivery of chemotherapy to the brain (Robey et al., 2018).

Because transporters affect drug efficacy and pharmacokinetics, it is important to know which compounds are substrates. This can affect decisions on how a drug is administered or whether or not the drug might be effective in the treatment of neurological diseases, and against drug-resistant tumor cells. Although the FDA offers guidelines for determining the interaction of investigational drugs with P-gp and ABCG2 (Lee et al., 2017), often these critical data are not published.

We implemented a systematic screen to identify cytotoxic substrates of P-gp. To do so, we developed high-throughput assays to examine differential cell killing between drug-naïve cancer cell lines and drug-selected, P-gp-overexpressing sublines. We screened several libraries of annotated compounds including the NCATS Pharmaceutical Collection (NPC), a comprehensive collection of all clinically approved drugs, along with small molecules with known mechanisms of action - either as probe small molecules or experimental therapeutics designed to modulate a wide range of targets, including many small molecules developed for oncology indications. Mechanistic annotation of these compounds can provide valuable insight 
into targets or pathways that appear to have been rendered more sensitive to inhibition in the course of multidrug resistance development. Hits from the primary screen were assessed against HEK cells over-expressing P-gp in the absence and presence of the P-gp inhibitor tariquidar. Top substrates were tested in a cell-killing synergy experiment with the inhibitors tariquidar or elacridar, demonstrating the consistent inhibition of P-gp by inhibitors irrespective of substrate.

\section{Materials and Methods}

Cell Lines. The HeLa derivative cell line, KB-3-1, and its colchicine-selected, P-gpoverexpressing subline, KB-8-5-11 were maintained in DMEM with 10\% FCS and Pen/Strep with glutamine at $37^{\circ} \mathrm{C}$ in $5 \% \mathrm{CO}_{2}$. For $\mathrm{KB}-8-5-11$ cells, colchicine was added to the medium at a concentration of $100 \mathrm{ng} / \mathrm{mL}$. HEK-293 cells transfected with empty vector (pcDNA) or vector containing human $A B C B 1$ (MDR-19) or $A B C G 2$ (R-5) have been described previously (Robey et al., 2011) and were maintained in EMEM supplemented with 10\% FCS, Pen/Strep and glutamine with $2 \mathrm{mg} / \mathrm{ml} \mathrm{G} 418$ to select for the expression of the transporter. Cultures were confirmed to be free of mycoplasma infection using the MycoAlert Mycoplasma Detection Kit (Lonza, Walkersville, MD). For the screen, assay medium was identical to culture medium except for KB-8-5-11 where colchicine was excluded from the medium.

Screening Libraries. The libraries that were used for the screen included the Mechanism Interrogation Plate (MIPE) comprised of 1,912 compounds (Mathews Griner et al., 2014), the NCATS pharmaceutical collection (NPC) comprised of 2816 compounds (Huang et al., 2011), the NCATS Pharmacologically Active Chemical Toolbox (NPACT) (Davis et al., 2016) comprised of 5,099 compounds, and a kinase inhibitor library comprised of 977 compounds, for a total of 10,804 compounds.

High Throughput Screen (HTS). All cell lines were plated into 1536-well plates at 500 cells/well in $5 \mu \mathrm{L}$ media. Compounds were then pinned in dose-response using a 1536-head pin tool (Kalypsis, San Diego, CA) and plates were incubated at $37{ }^{\circ} \mathrm{C}$ in $5 \% \mathrm{CO}_{2}$ for an additional $72 \mathrm{~h}$. CellTiter-Glo reagent (Promega) was dispensed into the wells, incubated for $5 \mathrm{~min}$ and luminescence was read on a ViewLux instrument (Perkin-Elmer). Cytotoxic compounds were defined as those that yielded a curve class of $-1.1,-1.2,-2.1,-2.2,-2.3$, or -2.4 , a maximum response of $\geq 50 \%$ and an AC50 of $\leq 10 \mu \mathrm{M}$. Cherry-picked hits from screening analysis were tested with both the KB pair of cell lines, and the pcDNA (empty vector control) and MDR-19 (P-gp overexpressing) pair were tested, in the absence and presence of tariquidar.

Confirmatory three-day cytotoxicity assays were also performed by plating pcDNA, MDR-19 or R-5 cells in 96-well, opaque white plates at a density of 5,000 cells/well and allowing them to attach overnight. Compounds were added at increasing concentrations and incubated with the cells for $72 \mathrm{~h}$ after which plates were analyzed using CellTiter-Glo according to the manufacturer's instructions.

Synergy Experiments. Synergy screens were performed with a subset of P-gp substrates identified by HTS in combination with the P-gp inhibitors tariquidar or elacridar. Plating of compounds in matrix format using acoustic droplet ejection and numerical characterization of synergy, additivity and/or antagonism were conducted as described previously (Martinez et al., 2016; Mathews Griner et al., 2014). Briefly, compounds were plated as a $10 \times 10$ dose response combination matrix. Concentration ranges were selected from single agent dose response curves 
generated from the HTS. Compounds were acoustically dispensed (10 nL/well) using an ATS100 (EDC Biosystems) onto 1,536-well, white, solid-bottom, TC-treated plates. KB-3-1 and KB$8-5-11$ cells were subsequently added to the plates $(500$ cells/well in $5 \mu \mathrm{l})$ and incubated for 72 hr at $37^{\circ} \mathrm{C}$ with $5 \% \mathrm{CO}_{2}$ under $85 \%$ humidity. Cell viability was determined by the addition of $2.5 \mu \mathrm{L}$ of CellTiter-Glo into to each well. After 15 min incubation at RT, each sample's luminescence intensity was measured using a ViewLux reader. DMSO (20 nL) and bortezomib $(20 \mathrm{~nL}$ at $2.3 \mathrm{mM})$ were used as negative and positive controls respectively. All P-gp substrates listed in Table 1 were tested against the P-gp inhibitors tariquidar and elacridar. Combinations were characterized using the Bliss model and summarized using the DBSumNeg metric.

ATPase Assay. The ATPase assay was performed as described previously (Ambudkar, 1998). Briefly, crude membrane protein $(100 \mu \mathrm{g} / \mathrm{ml})$ was isolated from Hi-Five insect cells expressing human P-gp. The vanadate-sensitive activity was calculated by measuring the end point phosphate release assay in the absence and presence of vanadate. Briefly, solutions containing $4.0 \mu \mathrm{g}$ of total membrane protein in $100 \mu \mathrm{L}$ of ATPase assay buffer $(50 \mathrm{mM}$ MESTris $\mathrm{pH}$ 6.8, $50 \mathrm{mM} \mathrm{KCl,} 5 \mathrm{mM}$ sodium azide, $1 \mathrm{mM}$ EGTA, $1 \mathrm{mM}$ ouabain, $2 \mathrm{mM}$ DTT, 10 $\mathrm{mM} \mathrm{MgCl} 2$ ) with $1 \%$ DMSO solvent alone (basal activity) or with variable concentrations $(0.1,1$ or $10 \mu \mathrm{M})$ of the substrates in DMSO were prepared. The tubes were incubated for $3 \mathrm{~min}$ at $37^{\circ} \mathrm{C}$, after which the reaction was initiated by addition of $5 \mathrm{mM}$ ATP. After 20 min incubation, the reaction was stopped by addition of $2.5 \% \mathrm{SDS}$. The amount of inorganic phosphate released was quantified by the colorimetric method, as previously described (Ambudkar, 1998).

Flow Cytometry. Transport assays were conducted as described previously (Robey et al., 2004). To measure inhibition of P-gp-mediated transport, trypsinized MDR-19 cells were incubated in phenol red-free IMEM supplemented with $10 \%$ FCS, Pen/Strep, and glutamine, containing $0.5 \mu \mathrm{g} / \mathrm{mL}$ rhodamine 123 (Sigma-Aldrich, St. Louis MO) in the presence or absence of $25 \mu \mathrm{M}$ of selected compounds identified by the screen for $30 \mathrm{~min}$ at $37^{\circ} \mathrm{C}$ in $5 \% \mathrm{CO}_{2}$. The medium was then removed and replaced with complete medium with or without the compound for an additional $1 \mathrm{~h}$. Valspodar (Apex Biotechnology, Houston, TX) at $3 \mu \mathrm{g} / \mathrm{mL}$ served as a positive control for P-gp inhibition. For ABCG2-mediated transport, R-5 cells were incubated in a similar fashion except $5 \mu \mathrm{M}$ pheophorbide A (PhA, Frontier Scientific, Logan, UT) was used as the substrate and $10 \mu \mathrm{M}$ fumitremorgin C (FTC, synthesized by the NIH Chemical Biology Laboratory, Bethesda, MD) served as the positive control for ABCG2 inhibition. Samples were analyzed on a FACSCanto II flow cytometer (BD Biosciences, San Jose, CA) in which rhodamine fluorescence was detected with a 488-nm argon laser and a 530-nm bandpass filter and $\mathrm{PhA}$ was detected using a 635-nm red diode laser and a 670-nm filter. At least 10,000 events were collected for each sample.

\section{Results}

High-throughput Screen to Identify P-gp Substrates. To identify novel substrates of P-gp, we used the CellTiter-Glo luminescent cell viability assay to test library compounds against three cell conditions: (1) the parental KB-3-1 human cervical adenocarcinoma cell line (a HeLa clone); (2) the drug-resistant subline KB-8-5-11 that over-expresses P-glycoprotein, and (3) the KB-8-5-11 cell line in the presence of the P-gp inhibitor tariquidar (which should restore sensitivity to P-gp substrates). Overall, 10,804 compounds were tested from across four annotated small molecule libraries. The NCATS Pharmaceutical Collection (NPC) is a library of 
compounds approved for use by the Food and Drug Administration and related agencies in foreign countries. The NCATS Pharmacologically Active Chemical Toolbox (NPACT) library contains pre-clinical and probe compounds from across disease areas. The kinase inhibitor library contains almost 1,000 small molecule inhibitors of kinases, with known mechanisms of action. The Mechanism Interrogation PlatE (MIPE) library contains oncology-focused compounds with known mechanisms of action.

The screen was designed based on the fundamental principle of P-gp-mediated drug resistance: substrates which kill or inhibit growth of KB-3-1 were expected to demonstrate reduced efficacy against the KB-8-5-11 cells due to drug efflux by P-gp. P-gp-specific efflux could be demonstrated by sensitization of KB-8-5-11 cells in the presence of the P-gp inhibitor tariquidar. As a cell viability assay was utilized for this screen, a limitation of the screen is that only cytotoxic or cytostatic P-gp substrates could be identified. Of 10,804 compounds tested, 1,362 compounds demonstrated cytotoxicity towards the KB-3-1 cells, of which 90 compounds were identified as putative P-gp substrates (Fig. 1A). In total, 13\% of all compounds tested demonstrated cytotoxicity towards the parental KB-3-1 cell line. Among the four libraries, the kinase inhibitor library (30\%) and oncology-focused MIPE library (21\%) contained the greatest proportion of cytotoxic compounds, followed by the NPACT library (10\%) (Fig. 1B). As one might anticipate, the NPC library of therapeutic agents contained the lowest proportion of cytotoxic compounds $(5 \%)$.

A comparison of the global response of the two cell lines to the library compounds was undertaken by assessing the area-under-the-curve (AUC) for each compound against each cell line (Fig. 1C). The AUC of the dose-response curve ensures both efficacy (magnitude of cell killing) and potency (concentration that elicits cell killing) are accounted for in the analysis of activity (Fig. 1A). The KB-3-1 cell line was more sensitive than the KB-8-5-11 cell line for a number of compounds, shown in Fig. 1C, where darker red correlates with greater sensitivity to a given compound, while lighter colors correlate with more resistance. This is consistent with the multidrug-resistant nature of the KB-8-5-11 cell line.

To pinpoint substrates identified by HTS, the difference in AUC between KB-3-1 and KB-8-5-11 cells was determined ( $\triangle \mathrm{AUC1}$, Fig. 2A). As an example, the HTS dose-response curves for vincristine (a known P-gp substrate) are displayed in Fig. 2A for all three conditions screened. As cell killing assays involve loss of signal, data were analyzed from $0 \%$ (positive control signal) to $-100 \%$ (complete cell killing/growth inhibition). The data represented in Fig. 2A is usual for HTS data analysis, but not normal for displaying cell killing data - elsewhere in this manuscript, data are displayed as is traditional for cell killing assays with $100 \%$ as control cell viability and $0 \%$ as total cell death. The AUC for the sensitive KB-3-1 cell line was determined for each compound (gray shading). The AUC for the resistant KB-8-5-11 cell line was also determined for each compound (red shading). The difference (delta) between the AUC for each cell line was determined (termed $\triangle \mathrm{AUC1}$ ), and the greater the magnitude of $\triangle \mathrm{AUC} 1$, the stronger the substrate effect of P-gp. This strategy is distinct from the commonly applied method used to discern $\mathrm{P}$-gp substrates by comparing the $\mathrm{IC}_{50}$ values derived from dose-response curves. The difference between KB-8-5-11 cells with and without the P-gp inhibitor tariquidar (1 $\mu \mathrm{M}$ ) was also assessed in order to confirm P-gp substrates (termed $\triangle \mathrm{AUC2}$ ). P-gp primary highthroughput screening data for KB-3-1 and KB-8-5-11 cell lines against NPC, NPACT MIPE and Kinase libraries was deposited in PubChem with AIDs 1346986 and 1346987, respectively. Assay data can be accessed via the following links: https://pubchem.ncbi.nlm.nih.gov/assay/assay.cgi?aid=1346986 for the KB-3-1 cell line, and https://pubchem.ncbi.nlm.nih.gov/assay/assay.cgi?aid=1346987 for the KB-8-5-11 cell line. 
Following plating of hits and re-testing for confirmation, a total of 90 P-gp substrates were identified (Supplementary Table 1) based on a $\triangle A U C 1$ cut-off value of 50. Comparison of identified substrates with the literature revealed 35 known P-gp substrates were identified in the screen, and 55 new substrates were identified. Comparison of $\triangle \mathrm{AUC} 1$ and $\triangle \mathrm{AUC} 2$ for all substrates revealed a strong correlation between parental cells and inhibited KB-8-5-11 cells in which P-gp was inhibited with tariquidar (Fig. 2B). To confirm that the putative P-gp substrates were not due to cell line-specific alterations, an orthogonal assay testing all hits against HEK 293 human embryonic kidney cells stably transfected with either plasmid control (pcDNA) or a plasmid expressing $A B C B 1$ (MDR-19), was conducted and and $\triangle \mathrm{AUC1}$ was calculated. A correlation was demonstrated between the KB-3-1/KB-8-5-11 $\triangle \mathrm{AUC1}$ and the pcDNA/MDR-19 $\triangle \mathrm{AUC1}$ (Fig. 2C). Unsupervised clustering of global cell response to the 90 substrates identified for the three $\mathrm{KB}$ and three HEK conditions (parent, resistant, resistant with tariquidar) demonstrated a consistent pattern, with the KB-8-5-11 and MDR-19 cell lines less sensitive to compounds compared to their parental partners, and the parent lines clustering with the resistant cell lines in the presence of tariquidar (Fig. 2D).

Assessment of P-gp Substrates. To confirm that the HTS assay and analysis strategy identifies substrates, we assessed the cell-killing activity of three known substrates included in the library (target in brackets): paclitaxel [tubulin] (Greenberger et al., 1988), vincristine [tubulin] (Horton et al., 1987), and mithramycin [RNA synthesis] (Biedler and Riehm, 1970) (Fig. 3A-C, respectively). Examples of the dose-response curves for three newly identified substrates are PKI-402 [PI3K/mTOR](Dehnhardt et al., 2010), CB300919 [NAMPT](Bavetsias et al., 2002), and PHA-793887 [CDK1/2/4](Brasca et al., 2010) (Fig. 3D-F, respectively). In each case, a strong difference in cell killing between parent and resistant cells was found.

To confirm that the newly identified substrates were indeed P-gp substrates, we performed confirmatory cytotoxicity assays in the laboratory using pcDNA and MDR-19 cells. We selected 6 commercially available, newly-identified P-gp substrates AT7159, a cyclindependent kinase (CDK) inhibitor; AT9283, a JAK2/3 inhibitor; ispinesib, a kinesin spindle protein inhibitor; gedatolisib (PKI-587), a PI3K/mTOR inhibitor; GSK-690693, an AKT inhibitor; and KW-2478, an HSP90 inhibitor. In addition, we examined the ability of ABCG2 to confer resistance to the compounds using ABCG2-overexpressing R-5 cells. As shown in Table 1, all of the compounds were confirmed to be P-gp substrates, with P-gp expression conferring less resistance to AT9283 (13-fold), but conferring very high levels of resistance to gedatolisib (1671-fold). All of the compounds were also found to be ABCG2 substrates to varying degrees. In the case of AT9283, GSK-690693 and gedatolisib, ABCG2 conferred relatively high levels of resistance, while ispinesib, AT7519 and KW-2478 were preferentially transported by P-gp.

Effect of Some Newly-Identified Substrates on ATPase Activity of P-gp. The ability of substrates to stimulate the ATPase activity of P-gp was assessed. Some kinase inhibitors that are P-gp substrates have been shown to significantly stimulate the ATPase activity of P-gp, while others do not (Hegedus et al., 2009). We omitted AT9283 from this assay, as P-gp conferred the lowest levels of resistance to this compound. The vanadate-sensitive ATPase activity of P-gp in the presence of $0.1,1$ or $10 \mu \mathrm{M}$ of each compound compared with the basal activity (activity in the presence of 1\% DMSO). As observed in Fig. 4A-E, we found that ispinesib stimulated ATPase activity in a concentration-dependent manner. Ispinesib stimulated the ATPase activity by $>2.6$ fold at concentrations greater than $1 \mu \mathrm{M}(1.6$ fold at $0.1 \mu \mathrm{M})$. KW-2478 was also capable of stimulating the ATPase activity, but only at higher concentrations $(10 \mu \mathrm{M})$ and only 
up to 1.4-fold. The rest of the compounds did not affect the ATPase activity in the range of concentrations tested. Of note, P-gp conferred the highest levels of resistance to gedatolisib in our studies but gedatolisib did not cause an increase in ATPase activity.

P-gp Inhibitors Synergize With Substrates. P-gp substrates were identified during the HTS in part by co-treating P-gp-expressing cells with the inhibitor tariquidar at a concentration $(1 \mu \mathrm{M})$ shown to fully inhibit P-gp, to demonstrate P-gp-specific resistance. To explore the nature of inhibitor-mediated sensitization of substrates, we assessed $10 \times 10$ combinations of tariquidar or elacridar with 17 P-gp substrates identified from the screen (Table 2). Viability was again measured using CellTiter-Glo, and the Bliss independence model was used to characterize the presence or absence of synergy for each combination, where negative $\Delta B$ liss represents synergy, and positive $\Delta$ Bliss represents antagonism.. We hypothesized that inhibitors should antagonize P-gp transport of substrates in P-gp-expressing cells, and that this approach could be used to compare the efficacy of P-gp inhibitors in combination with a range of substrates. This approach has not been previously adopted for studying $\mathrm{ABC}$ transporter inhibitors.

The effect of both tariquidar and elacridar across all substrates was uniform. Paclitaxel is shown as an example. Parental KB-3-1 cells were sensitive to paclitaxel (black $=100 \%$ viable, red $=0 \%$ viable), and this sensitivity was unaffected by addition of elacridar up to a concentration of $20 \mu \mathrm{M}$ (Fig. 5a). This is exemplified by the absence of any strong synergy (red) or antagonism (blue) (Fig. 5a), and in paclitaxel dose-response curves extracted from the 10x10 block (Fig. 5b). This relationship was observed for both inhibitors in combination with every Pgp substrate tested against parental cells. Elacridar and tariquidar alone had no effect on cell viability. The $10 \times 10$ blocks for parental KB-3-1 cell are available at https://tripod.nih.gov/matrix-client/rest/matrix/blocks/8067/table.

In contrast, the P-gp substrates demonstrated maximal synergy in combination with elacridar and tariquidar in P-gp-expressing KB-8-5-11 cells. The combination of paclitaxel and elacridar is shown as an example (Fig. 5c, 5d). In the absence of elacridar, paclitaxel demonstrated minimal cytotoxicity towards KB-8-5-11 cells, but addition of elacridar sensitized the cells to paclitaxel, with near-maximal effects at $82 \mathrm{nM}$ and higher. Dose-response curves from the $10 \times 10$ block demonstrate the sensitization of KB-8-5-11 cells to paclitaxel with increasing elacridar concentration (Fig. 5c), and this sensitization was accompanied by maximal synergy. Synergy was observed for both inhibitors in combination with every P-gp substrate tested against P-gp-expressing KB-8-5-11 cells. The 10 x 10 blocks for P-gp-expressing KB-8-511 cell are available at https://tripod.nih.gov/matrix-client/rest/matrix/blocks/8069/table.

To ascertain the inhibitory potency of tariquidar and elacridar, dose-response curves were extracted from the $10 \times 10$ block of each inhibitor against each compound. 15 of 17 compounds elicited near-complete cell killing, the exceptions being the Aurora kinase inhibitors tozasertib and danusertib, which had a maximal efficacy of approximately $50 \%$ (Fig. 5e, 5f). Tariquidar (Fig. 5e) and elacridar (Fig. 5f) both achieved near-complete inhibition of all compounds (maximal cell killing) at $247 \mathrm{nM}$, and the average $\mathrm{IC}_{50}$ against fifteen diverse substrates were 100 $\pm 49 \mathrm{nM}$ (cotreated with tariquidar) and $84 \pm 48 \mathrm{nM}$ (cotreated with elacridar), suggesting inhibition of P-gp irrespective of the substrate. $\mathrm{IC}_{50} \mathrm{~s}$ for inhibition of compounds were consistent with values in the literature, though there are no studies comparing inhibitors and testing them against a large number of substrates. 


\section{Newly-Identified P-gp Substrates Inhibit P-gp- and ABCG2-Mediated Transport.}

Many P-gp substrates have also been found to inhibit P-gp-mediated transport at relatively high concentrations and this is particularly true for kinase inhibitors (Durmus et al., 2015). We next assessed the ability of the six compounds identified earlier to inhibit P-gp-mediated rhodamine 123 transport or ABCG2-mediated pheophorbide A transport from MDR-19 or R5 cells, respectively, as shown in Fig. 6. At a concentration of $25 \mu \mathrm{M}$, only ispinesib was found to appreciably inhibit P-gp-mediated rhodamine transport and was nearly as effective as $3 \mu \mathrm{M}$ valspodar. Ispinesib was also the only compound found to appreciably inhibit pheophorbide A transport, although not as well as fumitremorgin $\mathrm{C}$, which served as a positive control for ABCG2 inhibition. In agreement with previous reports, we find that some kinase inhibitors are substrates of transporters at low concentrations, but then act as inhibitors at higher concentrations.

\section{Discussion}

P-gp and ABCG2 are known to play a role in the disposition of many toxins by limiting oral bioavailability, increasing excretion, and limiting brain penetration (Robey et al., 2018). While many targeted therapies have been developed, often it is unclear what role transporters might play in their disposition and how they might affect therapy. We therefore developed a high-throughput screening assay to identify novel substrates of P-gp. Using KB-3-1 cells that do not express P-gp and their P-gp-overexpressing KB-8-5-11 counterpart, we identified 55 novel substrates of P-gp that were confirmed in a second pair of cell lines both in the primary screen and secondary assays. These data will be valuable to researchers who are seeking novel treatments for brain cancers or metastases, as compounds that are transported by P-gp will most likely not cross the blood-brain barrier, as shown by mouse knockout models (Robey et al., 2018).

Previous screens have used alternative methods to identify novel P-gp substrates. The NCI-60 drug screen cell line set was previously used to identify P-gp substrates based on measuring rhodamine 123 transport (Lee et al., 1994) or $A B C B 1$ gene expression data (Alvarez et al., 1995; Szakacs et al., 2004) in the 60 cell lines of the screen and comparing that to drug sensitivity profiles. Cell lines with higher levels of P-gp expression were found to correlate with decreased sensitivity to substrate drugs. This method was successful due to the relatively high level of variation of P-gp expression in the lines of the screen. In the case of ABCC1 or ABCG2, with cells expressing much lower levels of the transporters, the screen was less successful and often did not identify known substrates (Alvarez et al., 1998; Deeken et al., 2009). More recently our group developed an assay based on a dual-fluorescent system, in which sensitive cells (OVCAR8) were transduced to express DsRed red fluorescent protein and P-gp overexpressing cells (NCI/ADR-RES) expressed enhanced green fluorescent protein (Brimacombe et al., 2009).

The present study, and those referenced above, rely on P-gp to protect cells from cell death. While appropriate for a study such as this examining cancer drug resistance, a limitation of this approach is that non-toxic compounds cannot be studied. Strategies for studying non-toxic substrates have been explored, and rely on either direct monitoring of the test compounds (for example, radioactivity or analytical detection), or interference with the efflux of a fluorescent substrate. The primary example of the latter comes from Sklar and co-workers, who have reported a number of screens using flow cytometry to identify inhibitors of ABC transporters (Ivnitski-Steele et al., 2008; Strouse et al., 2013a; Strouse et al., 2013b; Winter et al., 2008). A Pfizer study reported a correlation between MDCK cells transfected with mouse (Mdrla) and 
human (MDR1) P-gp for 3300 compounds, using LC-MS for analytical quantitation of each compound, although the compounds themselves were not disclosed (Feng et al., 2008). Further work is needed to tabulate all pharmacologically active drugs that are P-gp substrates.

Of course, high-throughput screening methods do have limitations. First, the compounds must be toxic and/or cause cell cycle arrest so that differences between treated and untreated cells can be detected by the CellTiter Glo assay. Thus, the assay will not detect all substrates. Additionally, the ability of a drug to inhibit growth or elicit toxicity often depends on the choice of cell line model. For example, while mutant BRAF inhibitors were among the compounds tested, none emerged as potential substrates despite the fact that some of them such as vemurafenib and dabrafenib were reported to be substrates of P-gp (Mittapalli et al., 2013; Mittapalli et al., 2012). This is not unexpected, as the cell line model systems we used did not harbor a mutant BRAF gene. Among the substrates identified, there were no MEK inhibitors, although trametinib and cobimetinib are both known to be P-gp substrates (Choo et al., 2014; de Gooijer et al., 2017). This is most likely due to the fact that the cell line models used did not harbor mutations in BRAF or Ras. Therefore, while this assay did identify several new substrates of P-gp, it does not represent a definitive way to determine if a compound is a P-gp substrate.

Synergy is an important concept in combination chemotherapy, but it is not often discussed in the context of transport inhibitors. Utilizing the Bliss calculation, we demonstrated the profound synergy that inhibition of P-gp can produce in combination with avid P-gp substrates. An advantage of the $10 \times 10$ combination grid is the ability to readily examine the effects of inhibitors on P-gp substrates. After the initial screen, the ability of the inhibitors tariquidar and elacridar were tested in increasing concentrations with the 17 substrates identified by the screen. Both inhibitors were found to synergize with the substrates, and to act at a consistent concentration in combination with all compounds tested. The sensitivity of the synergy screening approach suggests that it may be an alternative strategy to identify P-gp substrates, and could potentially be used to detect non-cytotoxic substrates that are also competitive inhibitors.

In conclusion, we have developed a high-throughput screen to identify substrates of P-gp. We identified 55 novel substrates, among them targeted therapies that have yet to be developed clinically. We also have demonstrated that our method can be easily used to confirm the action of proposed P-gp inhibitors by sensitizing P-gp-overexpressing cells to numerous substrates. Future studies will focus on translating these techniques to the identification of substrates of other $\mathrm{ABC}$ transporters.

\section{Acknowledgements}

We appreciate the technical assistance of George Leiman. The content of this publication does not necessarily reflect the views or policies of the Department of Health and Human Services, nor does mention of trade names, commercial products, or organizations imply endorsement by the U.S. Government.

\section{Authorship Contributions}

Participated in research design: TDL, OWL, KRB, RWR, SVA, MMG, MDH

Conducted experiments: TDL, OWL, LC, RG, SL, BGT, RWR

Performed data analysis: TDL, OWL, LC, RG, SL, RWR, SVA, MS

Wrote or contributed to the writing of the manuscript: TDL, SL, RWR, MDH 


\section{References}

Alvarez M, Paull K, Monks A, Hose C, Lee JS, Weinstein J, Grever MR, Bates SE and Fojo AT (1995) Generation of a drug resistance profile by quantitation of mdr-1/P-glycoprotein in the cell lines of the NCI anticancer drug screen. JClinInvest 95: 2205-2214.

Alvarez M, Robey R, Sandor V, Nishiyama K, Matsumoto Y, Paull K, Bates S and Fojo T (1998) Using the national cancer institute anticancer drug screen to assess the effect of MRP expression on drug sensitivity profiles. Mol Pharmacol 54: 802-814.

Ambudkar SV (1998) Drug-stimulatable ATPase activity in crude membranes of human MDR1transfected mammalian cells. Methods Enzymol 292: 504-514.

Basseville A, Hall MD, Chau CH, Robey RW, Gottesman M, Figg WD and Bates SE (2016) The ABCG2 Multidrug Transporter, in ABC Transporters - 40 Years on (George MA ed) pp 195-226, Springer International Publishing, Cham.

Bavetsias V, Skelton LA, Yafai F, Mitchell F, Wilson SC, Allan B and Jackman AL (2002) The design and synthesis of water-soluble analogues of CB30865, a quinazolin-4-one-based antitumor agent. J Med Chem 45: 3692-3702.

Biedler JL and Riehm H (1970) Cellular resistance to actinomycin D in Chinese hamster cells in vitro: cross-resistance, radioautographic, and cytogenetic studies. Cancer Res 30: 11741184.

Brasca MG, Albanese C, Alzani R, Amici R, Avanzi N, Ballinari D, Bischoff J, Borghi D, Casale E, Croci V, Fiorentini F, Isacchi A, Mercurio C, Nesi M, Orsini P, Pastori W, Pesenti E, Pevarello P, Roussel P, Varasi M, Volpi D, Vulpetti A and Ciomei M (2010) Optimization of 6,6-dimethyl pyrrolo[3,4-c]pyrazoles: Identification of PHA-793887, a potent CDK inhibitor suitable for intravenous dosing. Bioorg Med Chem 18: 1844-1853.

Brimacombe KR, Hall MD, Auld DS, Inglese J, Austin CP, Gottesman MM and Fung KL (2009) A dual-fluorescence high-throughput cell line system for probing multidrug resistance. Assay Drug Dev Technol 7: 233-249.

Choo EF, Ly J, Chan J, Shahidi-Latham SK, Messick K, Plise E, Quiason CM and Yang L (2014) Role of P-glycoprotein on the brain penetration and brain pharmacodynamic activity of the MEK inhibitor cobimetinib. Mol Pharm 11: 4199-4207.

Cooray HC, Blackmore CG, Maskell L and Barrand MA (2002) Localisation of breast cancer resistance protein in microvessel endothelium of human brain. Neuroreport 13: 20592063.

Cordon-Cardo C, O'Brien JP, Casals D, Rittman-Grauer L, Biedler JL, Melamed MR and Bertino JR (1989) Multidrug-resistance gene (P-glycoprotein) is expressed by endothelial cells at blood-brain barrier sites. Proc Natl Acad Sci USA 86: 695-698.

Davis MI, Patrick SL, Blanding WM, Dwivedi V, Suryadi J, Golden JE, Coussens NP, Lee OW, Shen M, Boxer MB, Hall MD, Sharlow ER, Drew ME and Morris JC (2016) Identification of Novel Plasmodium falciparum Hexokinase Inhibitors with Antiparasitic Activity. Antimicrob Agents Chemother 60: 6023-6033.

de Gooijer MC, Zhang P, Weijer R, Buil LCM, Beijnen JH and van Tellingen O (2017) The impact of P-glycoprotein and breast cancer resistance protein on the brain pharmacokinetics and pharmacodynamics of a panel of MEK inhibitors. Int J Cancer.

Deeken J, Robey R, Shukla S, Steadman K, Chakraborty A, Poonkuzhali B, Schuetz E, Holbeck S, Ambudkar S and Bates S (2009) Identification of compounds that correlate with ABCG2 transporter function in the National Cancer Institute Anticancer Drug Screen. Mol Pharmacol 76: 946-956. 
Dehnhardt CM, Venkatesan AM, Delos Santos E, Chen Z, Santos O, Ayral-Kaloustian S, Brooijmans N, Mallon R, Hollander I, Feldberg L, Lucas J, Chaudhary I, Yu K, Gibbons J, Abraham R and Mansour TS (2010) Lead optimization of N-3-substituted 7morpholinotriazolopyrimidines as dual phosphoinositide 3-kinase/mammalian target of rapamycin inhibitors: discovery of PKI-402. J Med Chem 53: 798-810.

Durmus S, Hendrikx JJ and Schinkel AH (2015) Apical ABC transporters and cancer chemotherapeutic drug disposition. Adv Cancer Res 125: 1-41.

Feng B, Mills JB, Davidson RE, Mireles RJ, Janiszewski JS, Troutman MD and de Morais SM (2008) In vitro P-glycoprotein assays to predict the in vivo interactions of P-glycoprotein with drugs in the central nervous system. Drug Metab Dispos 36: 268-275.

Fetsch P, Abati A, Litman T, Morisaki K, Honjo Y, Mittal K and Bates S (2006) Localization of the ABCG2 mitoxantrone resistance-associated protein in normal tissues. Cancer Lett 235: 84-92.

Gottesman MM, Lavi O, Hall MD and Gillet JP (2016) Toward a Better Understanding of the Complexity of Cancer Drug Resistance. Annu Rev Pharmacol Toxicol 56: 85-102.

Greenberger LM, Lothstein L, Williams SS and Horwitz SB (1988) Distinct P-glycoprotein are overproduced in independently isolated drug-resistant cell lines. ProcNatlAcadSciUSA 85: 3762-3766.

Hegedus C, Ozvegy-Laczka C, Apáti A, Magócsi M, Német K, Orfi L, Kéri G, Katona M, Takáts Z, Váradi A, Szakács G and Sarkadi B (2009) Interaction of nilotinib, dasatinib and bosutinib with ABCB1 and ABCG2: implications for altered anti-cancer effects and pharmacological properties. Br J Pharmacol 158: 1153-1164.

Horton JK, Houghton PJ and Houghton JA (1987) Reciprocal cross-resistance in human rhabdomyosarcomas selected in vivo for primary resistance to vincristine and Lphenylalanine mustard. Cancer Res 47: 6288-6293.

Huang R, Southall N, Wang Y, Yasgar A, Shinn P, Jadhav A, Nguyen DT and Austin CP (2011) The NCGC pharmaceutical collection: a comprehensive resource of clinically approved drugs enabling repurposing and chemical genomics. Sci Transl Med 3: 80ps16.

Huls M, Brown CD, Windass AS, Sayer R, van den Heuvel JJ, Heemskerk S, Russel FG and Masereeuw R (2008) The breast cancer resistance protein transporter ABCG2 is expressed in the human kidney proximal tubule apical membrane. Kidney Int 73: 220225.

Ivnitski-Steele I, Larson RS, Lovato DM, Khawaja HM, Winter SS, Oprea TI, Sklar LA and Edwards BS (2008) High-throughput flow cytometry to detect selective inhibitors of ABCB1, ABCC1, and ABCG2 transporters. Assay Drug Dev Technol 6: 263-276.

Jonker JW, Smit JW, Brinkhuis RF, Maliepaard M, Beijnen JH, Schellens JH and Schinkel AH (2000) Role of breast cancer resistance protein in the bioavailability and fetal penetration of topotecan. J Natl Cancer Inst 92: 1651-1656.

Kort A, van Hoppe S, Sparidans RW, Wagenaar E, Beijnen JH and Schinkel AH (2017) Brain Accumulation of Ponatinib and Its Active Metabolite, N-Desmethyl Ponatinib, Is Limited by P-Glycoprotein (P-GP/ABCB1) and Breast Cancer Resistance Protein (BCRP/ABCG2). Mol Pharm 14: 3258-3268.

Lee JS, Paull K, Alvarez M, Hose C, Monks A, Grever M, Fojo AT and Bates SE (1994) Rhodamine efflux patterns predict P-glycoprotein substrates in the National Cancer Institute Drug Screen. Mol Pharmacol 46: 627-638.

Lee SC, Arya V, Yang X, Volpe DA and Zhang L (2017) Evaluation of transporters in drug development: Current status and contemporary issues. Adv Drug Deliv Rev 116: 100-118. 
Maliepaard M, Scheffer GL, Faneyte IF, van Gastelen MA, Pijnenborg AC, Schinkel AH, van De Vijver MJ, Scheper RJ and Schellens JH (2001) Subcellular localization and distribution of the breast cancer resistance protein transporter in normal human tissues. Cancer Res 61: 3458-3464.

Martinez NJ, Rai G, Yasgar A, Lea WA, Sun H, Wang Y, Luci DK, Yang SM, Nishihara K, Takeda S, Sagor M, Earnshaw I, Okada T, Mori K, Wilson K, Riggins GJ, Xia M, Grimaldi M, Jadhav A, Maloney DJ and Simeonov A (2016) A High-Throughput Screen Identifies 2,9-Diazaspiro[5.5]Undecanes as Inducers of the Endoplasmic Reticulum Stress Response with Cytotoxic Activity in 3D Glioma Cell Models. PLoS One 11: e0161486.

Mathews Griner LA, Guha R, Shinn P, Young RM, Keller JM, Liu D, Goldlust IS, Yasgar A, McKnight C, Boxer MB, Duveau DY, Jiang JK, Michael S, Mierzwa T, Huang W, Walsh MJ, Mott BT, Patel P, Leister W, Maloney DJ, Leclair CA, Rai G, Jadhav A, Peyser BD, Austin CP, Martin SE, Simeonov A, Ferrer M, Staudt LM and Thomas CJ (2014) Highthroughput combinatorial screening identifies drugs that cooperate with ibrutinib to kill activated B-cell-like diffuse large B-cell lymphoma cells. Proc Natl Acad Sci U S A 111: 2349-2354.

Mittapalli RK, Vaidhyanathan S, Dudek AZ and Elmquist WF (2013) Mechanisms limiting distribution of the threonine-protein kinase B-RaF(V600E) inhibitor dabrafenib to the brain: implications for the treatment of melanoma brain metastases. J Pharmacol Exp Ther 344: 655-664.

Mittapalli RK, Vaidhyanathan S, Sane R and Elmquist WF (2012) Impact of P-glycoprotein $(\mathrm{ABCB} 1)$ and breast cancer resistance protein $(\mathrm{ABCG} 2)$ on the brain distribution of a novel BRAF inhibitor: vemurafenib (PLX4032). J Pharmacol Exp Ther 342: 33-40.

Robey RW, Lin B, Qiu J, Chan LL and Bates SE (2011) Rapid detection of ABC transporter interaction: potential utility in pharmacology. J Pharmacol Toxicol Methods 63: 217-222.

Robey RW, Pluchino KM, Hall MD, Fojo AT, Bates SE and Gottesman MM (2018) Revisiting the role of ABC transporters in multidrug-resistant cancer. Nat Rev Cancer 18: 452-464.

Robey RW, Steadman K, Polgar O, Morisaki K, Blayney M, Mistry P and Bates SE (2004) Pheophorbide a is a specific probe for ABCG2 function and inhibition. Cancer Res 64: 1242-1246.

Schinkel AH, Smit JJ, van Tellingen O, Beijnen JH, Wagenaar E, van Deemter L, Mol CA, van der Valk MA, Robanus-Maandag EC and te Riele HP (1994) Disruption of the mouse mdrla P-glycoprotein gene leads to a deficiency in the blood-brain barrier and to increased sensitivity to drugs. Cell 77: 491-502.

Sparreboom A, van Asperen J, Mayer U, Schinkel AH, Smit JW, Meijer DK, Borst P, Nooijen WJ, Beijnen JH and van Tellingen O (1997) Limited oral bioavailability and active epithelial excretion of paclitaxel (Taxol) caused by P-glycoprotein in the intestine. Proc Natl Acad Sci U S A 94: 2031-2035.

Strouse JJ, Ivnitski-Steele I, Khawaja HM, Perez D, Ricci J, Yao T, Weiner WS, Schroeder CE, Simpson DS, Maki BE, Li K, Golden JE, Foutz TD, Waller A, Evangelisti AM, Young SM, Chavez SE, Garcia MJ, Ursu O, Bologa CG, Carter MB, Salas VM, Gouveia K, Tegos GP, Oprea TI, Edwards BS, Aubé J, Larson RS and Sklar LA (2013a) A selective ATP-binding cassette subfamily $\mathrm{G}$ member 2 efflux inhibitor revealed via highthroughput flow cytometry. J Biomol Screen 18: 26-38.

Strouse JJ, Ivnitski-Steele I, Waller A, Young SM, Perez D, Evangelisti AM, Ursu O, Bologa CG, Carter MB, Salas VM, Tegos G, Larson RS, Oprea TI, Edwards BS and Sklar LA 
(2013b) Fluorescent substrates for flow cytometric evaluation of efflux inhibition in ABCB1, ABCC1, and ABCG2 transporters. Anal Biochem 437: 77-87.

Szakacs G, Annereau JP, Lababidi S, Shankavaram U, Arciello A, Bussey KJ, Reinhold W, Guo Y, Kruh GD, Reimers M, Weinstein JN and Gottesman MM (2004) Predicting drug sensitivity and resistance: profiling ABC transporter genes in cancer cells. Cancer Cell 6: 129-137.

Thiebaut F, Tsuruo T, Hamada H, Gottesman MM, Pastan I and Willingham MC (1987) Cellular localization of the multidrug resistance gene product P-glycoprotein in normal human tissues. Proc Natl Acad Sci U S A 84: 7735-7738.

Thiebaut F, Tsuruo T, Hamada H, Gottesman MM, Pastan I and Willingham MC (1989) Immunohistochemical localization in normal tissues of different epitopes in the multidrug transport protein P170: evidence for localization in brain capillaries and crossreactivity of one antibody with a muscle protein. J Histochem Cytochem 37: 159-164.

Winter SS, Lovato DM, Khawaja HM, Edwards BS, Steele ID, Young SM, Oprea TI, Sklar LA and Larson RS (2008) High-throughput screening for daunorubicin-mediated drug resistance identifies mometasone furoate as a novel ABCB1-reversal agent. J Biomol Screen 13: 185-193. 


\section{Figure legends}

Fig. 1. Overview of high-throughput screening data. (A) Hit triage from HTS library screen (10,804 compounds), to compounds that are cytotoxic towards parental KB-3-1 cells (1,362 compounds) to identified P-gp substrates (90 compounds). (B) Summary of percentage of cytotoxic compounds, cumulative and represented in each library screened. (C) Area under the curve (AUC) heatmap of compound activity for screen hits, where red intensity represents magnitude of AUC: strong red is strongest cytotoxicity, and white represents no cytotoxicity.

Fig. 2. Summary of P-gp substrate analysis. (A) Summary of data analysis. For each compound, data is displayed as 'loss of signal from baseline', where $-100 \%$ represents total cell killing. KB3-1 cells are sensitive (black), KB-8-5-11 cells are resistant (red) but sensitized when P-gp inhibitor tariquidar is added (blue), top left. To perform HTS data analysis, AUC is determined for parent line (top right, grey) and resistant line (bottom left, pink). The difference in AUC (termed $\triangle \mathrm{AUC1}$ ) is used to identify putative substrates. $\triangle \mathrm{AUC1}$ was calculated by difference between resistant cells in the absence and presence of tariquidar. Comparison of the AUC for substrates calculated using $\triangle \mathrm{AUC1}$ and $\triangle \mathrm{AUC} 2$, assessing (B) rank order of substrates (where largest $\triangle \mathrm{AUC}$ is strongest substrate) and (C) orthogonal data generated testing $\mathrm{P}$-gp substrates against HEK cells. (D) Unsupervised clustering of compound activity against parent and resistant lines (with and without tariquidar), where strong red represents greatest cytoxicity..

Fig. 3. Representative examples of known (A-C) and previously unidentified (D-F) substrates of P-gp.

Fig. 4. Effects of novel P-gp substrates on ATPase activity. The vanadate-sensitive activity of Pgp was determined as outlined in Materials and Methods. Basal P-gp ATPase activity was compared to activity in the presence of $0.1,1$ or $10 \mu \mathrm{M}$ of the substrates (A) ispinesib, (B) KW2478, (C) GSK-690693, (D) AT7519 or (E) gedatolisib. Graphs depict average values from three independent experiments (error bars $+/-\mathrm{SD}$ ).

Fig. 5. Substrate synergy with P-gp inhibitors. Sample combination of elacridar and paclitaxel tested in 10x10 dose-response matrices with KB-3-1 (A) and KB-8-3-11 (B) . Left, percent response of cell viability where red $=$ cell death. Middle, magenta $=$ synergy. Rightdose-response curves extracted from synergy blocks for paclitaxel with increasing concentration of elacridar. Dose-response curves for (E) tariquidar and (F) elacridar for all substrates tested (listed in Table 2).

Fig. 6. Ispinesib inhibits P-gp- and ABCG2-mediated transport. P-gp overexpressing MDR-19 cells or ABCG2 overexpressing R-5 cells were incubated with $0.5 \mu \mathrm{g} / \mathrm{ml}$ rhodamine 123 or $5 \mu \mathrm{M}$ pheophorbide $\mathrm{A}$, respectively, in the absence or presence a specific inhibitor $(3 \mu \mathrm{M}$ valspodar for P-gp and $10 \mu \mathrm{M}$ FTC for ABCG2) or $25 \mu \mathrm{M}$ ispinesib for 30 min after which the medium was remove and replaced with substate-free medium continuing without or with the inhibitor. Cells incubated with substrates alone are shown by the red histogram, cells incubated with the substrate and specific inhibitor are shown by the orange histogram and cells incubated with the substrate and ispinesib are shown by the blue histogram. Results from one of two experiments are shown. 
bioRxiv preprint doi: https://doi.org/10.1101/528992; this version posted January 23, 2019. The copyright holder for this preprint (which was not certified by peer review) is the author/funder, who has granted bioRxiv a license to display the preprint in perpetuity. It is made available under aCC-BY 4.0 International license.

Table 1. Cross resistance profile for novel P-gp substrates in P-gp- or ABCG2-expressing cells

\begin{tabular}{|c|c|c|c|c|c|c|}
\hline Compound & Structure & $\begin{array}{l}\text { IC50 pcDNA } \\
(\mu \mathrm{M})\end{array}$ & $\begin{array}{l}\text { IC50 MDR- } \\
19(\mu \mathrm{M})\end{array}$ & $\begin{array}{l}\text { RR*P- } \\
\text { gp }\end{array}$ & $\begin{array}{l}\text { IC50 R-5 } \\
(\mu M)\end{array}$ & $\begin{array}{l}\text { RR* } \\
\text { ABCG2 }\end{array}$ \\
\hline AT7519 & & $0.61 \pm .075$ & $66.7 \pm 28.2$ & 110 & $2.3 \pm 0.2$ & 4 \\
\hline AT9283 & & $2.7 \pm .092$ & $34.8 \pm 6.8$ & 13 & $60.8 \pm 1.9$ & 22 \\
\hline Ispinesib & & $0.044 \pm 0.037$ & $2.8 \pm 0.51$ & 64 & $0.14 \pm 0.092$ & 3 \\
\hline Gedatolisib & & $0.028 \pm 0.0076$ & $47.2 \pm 12.8$ & 1672 & $2.0 \pm 0.30$ & 70 \\
\hline GSK-690693 & & $0.19 \pm 0.026$ & $56.2 \pm 18.8$ & 290 & $11.6 \pm 1.8$ & 60 \\
\hline KW-2478 & & $0.48 \pm 0.043$ & $129.7 \pm 27.5$ & 270 & $4.5 \pm 0.17$ & 9 \\
\hline
\end{tabular}

Results presented are $\mathrm{IC}_{50}$ values $+/$ - standard deviation.

*Relative resistance $(\mathrm{RR})$ value is the ratio of the $\mathrm{IC}_{50}$ values of $\mathrm{P}$-gp- or ABCG2-expressing cells (MDR-19 or R-5) to the $\mathrm{IC}_{50}$ values of pcDNA cells. 
Table 2. P-gp substrates tested in combination with elacridar and tariquidar

\begin{tabular}{|l|l|}
\hline Compound & Mechanism of Action \\
\hline Mithramycin A & Alcohol Dehydrogenase Inhibitor \\
\hline Danusertib & Aurora-A/B/C Kinase Inhibitor \\
\hline Tozasertib & Aurora-A/B/C Kinase Inhibitor \\
\hline PHA-793887 & CDK1,2,3,4,5 Inhibitor \\
\hline Romidepsin & Histone Deacetylase (HDAC) Inhibitor \\
\hline JNK-IN-7 & JNK inhibitor \\
\hline PKI-587 & mTOR inhibitor \\
\hline CB 300919 & NAMPT inhibitor \\
\hline PF-05212384 & PI3K Inhibitor \\
\hline AST-487 & RET kinase inhibitor \\
\hline Sepantronium Bromide & Survivin inhibitor \\
\hline Docetaxel & Tubulin polymerization promoter \\
\hline Paclitaxel & Tubulin polymerization promoter \\
\hline ROAnorelbine & Tylin polymerization inhibitor \\
\hline & \\
\hline & \\
\hline
\end{tabular}


bioRxiv preprint doi: https://doi.org/10.1101/528992; this version posted January 23, 2019. The copyright holder for this preprint (which was not certified by peer review) is the author/funder, who has granted bioRxiv a license to display the preprint in perpetuity. It is made available under aCC-BY 4.0 International license.

\section{Figure 1}

A

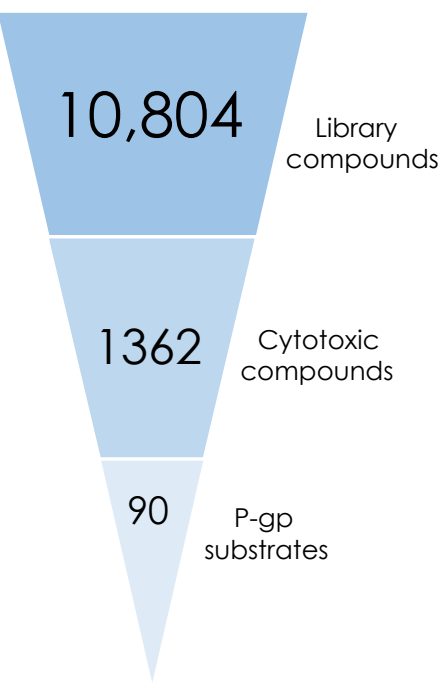

B

CUMULATIVE
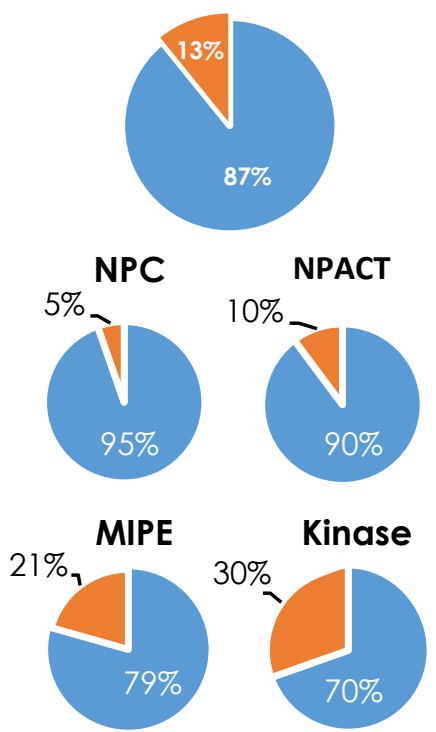

C
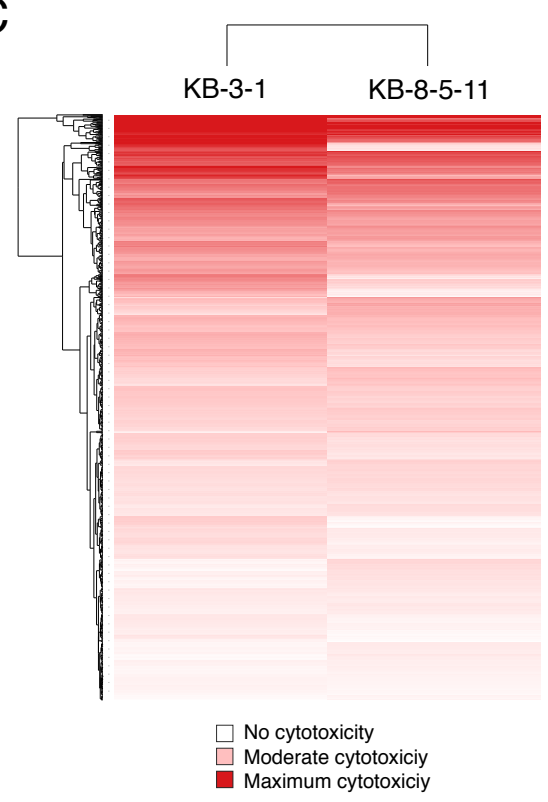
bioRxiv preprint doi: https://doi.org/10.1101/528992; this version posted January 23, 2019. The copyright holder for this preprint (which was not certified by peer review) is the author/funder, who has granted bioRxiv a license to display the preprint in perpetuity. It is made available under aCC-BY 4.0 International license.

\section{Figure 2}
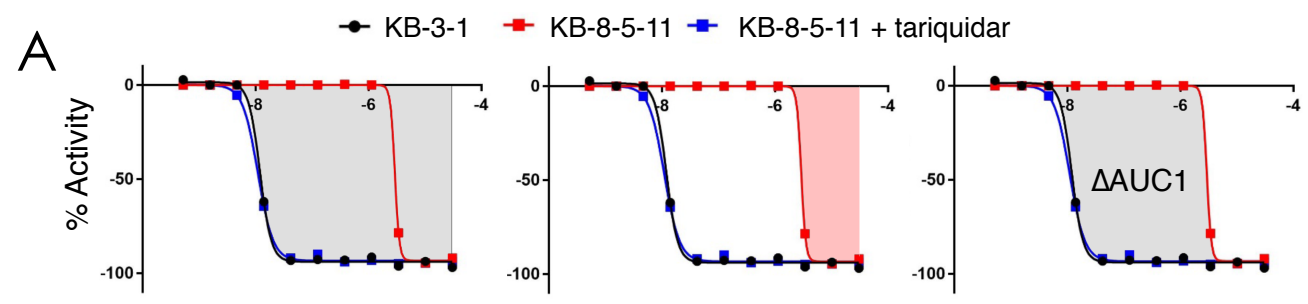

B
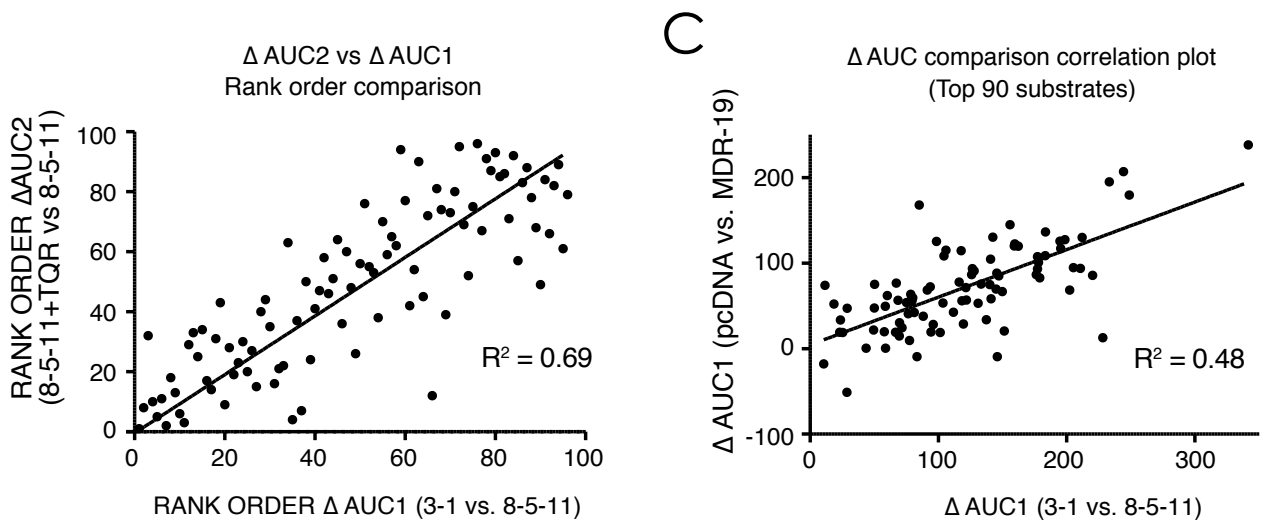

D

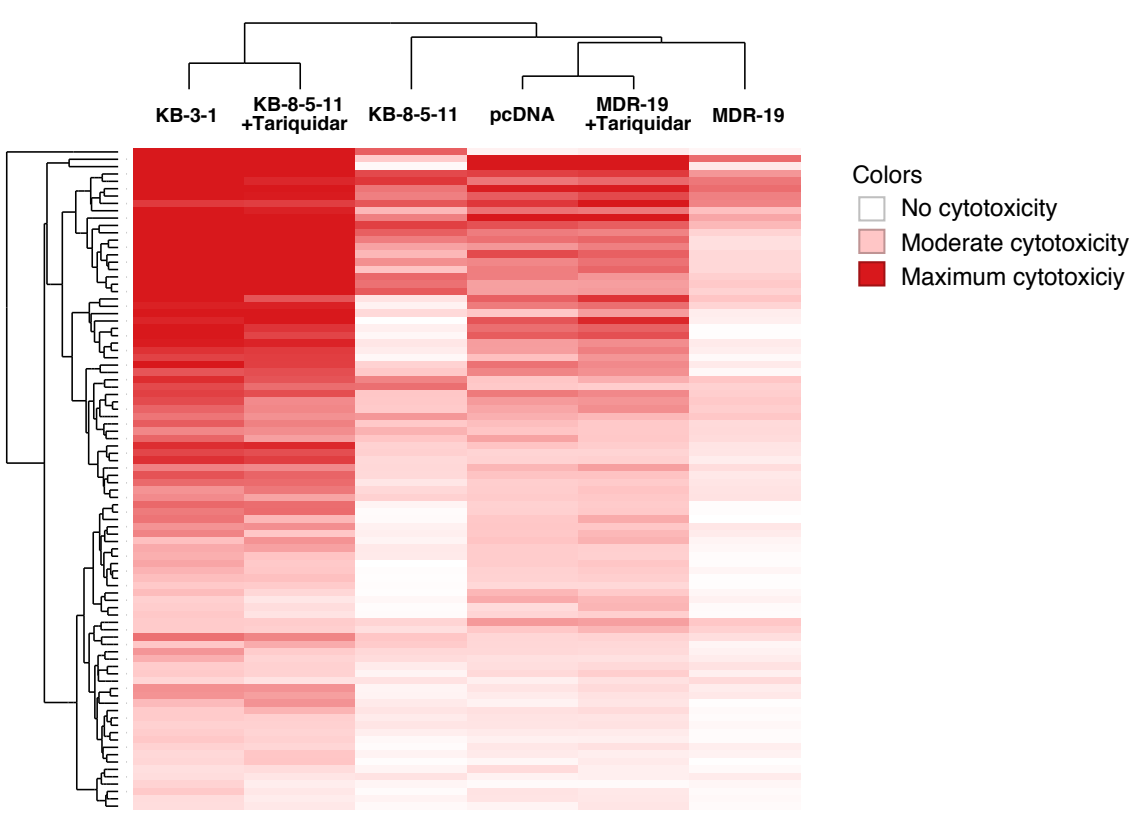


bioRxiv preprint dol: https://doi.org/10.1101/528992; this version posted January 23, 2019. The copyright holder for this preprint (which was not certified by peer review) is the author/funder, who has granted bioRxiv a license to display the preprint in perpetuity. It is made available under aCC-BY 4.0 International license.

Figure 3

A

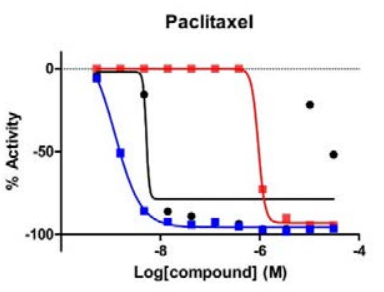

B

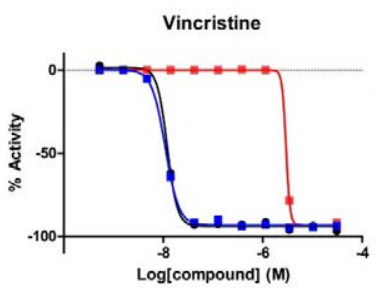

C

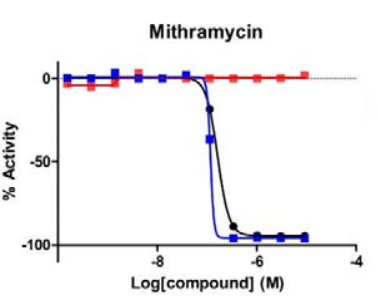

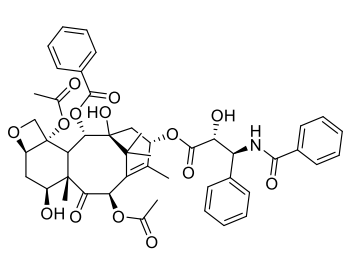

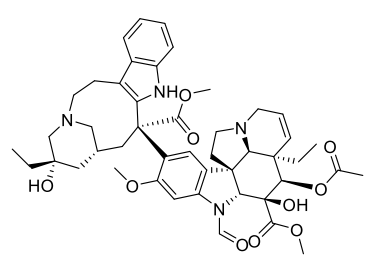

E

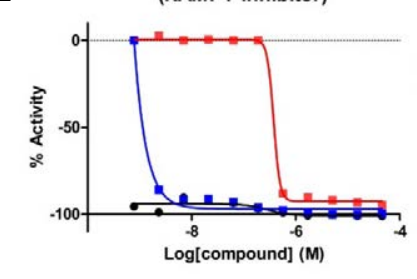

F

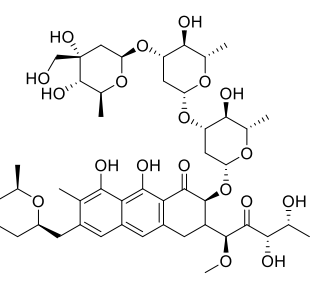

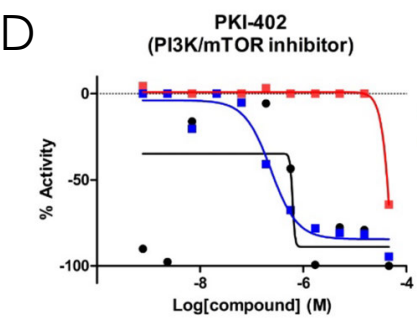
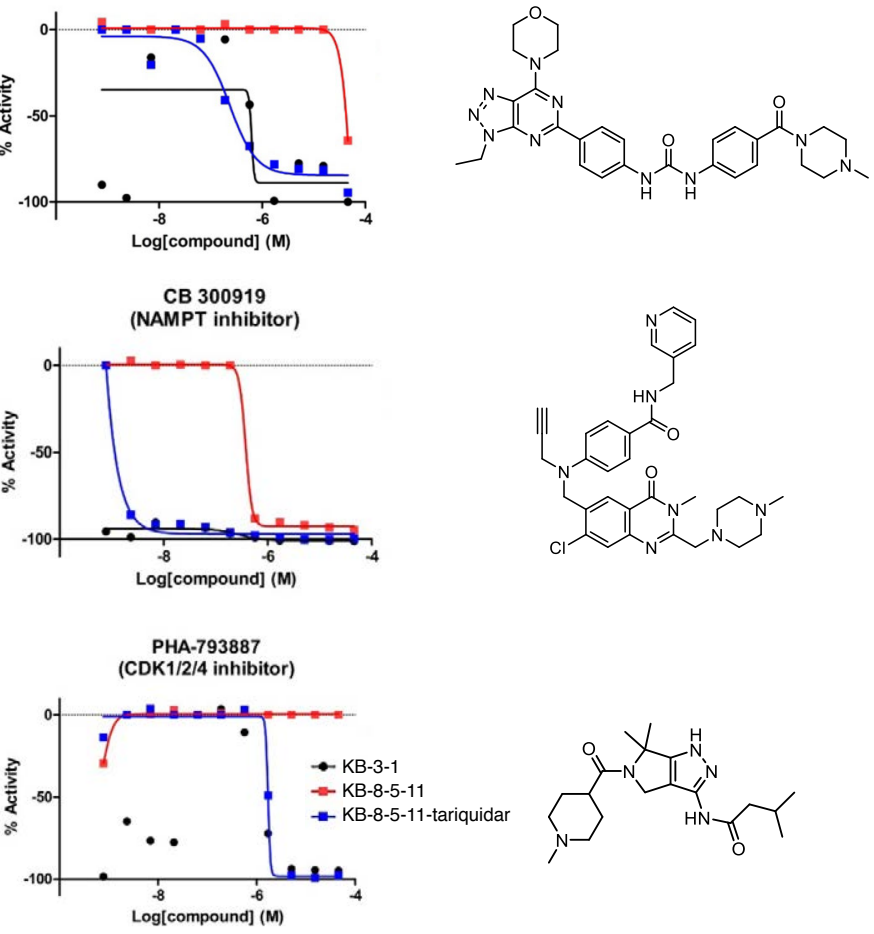
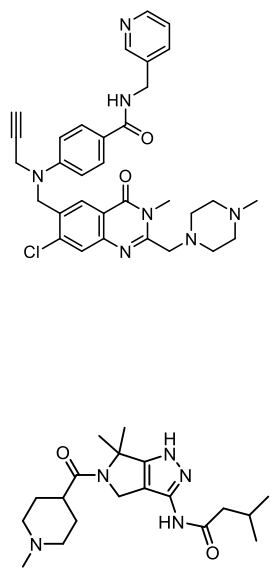


\section{Figure 4}

A

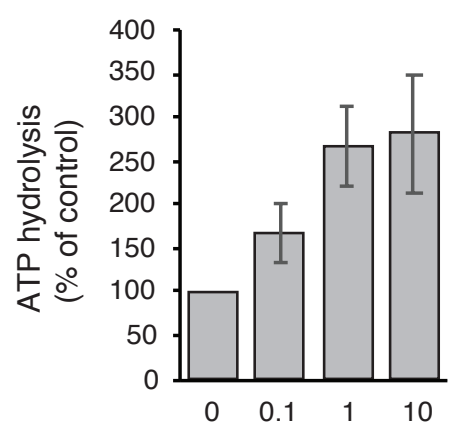

Ispinesib $(\mu \mathrm{M})$

D

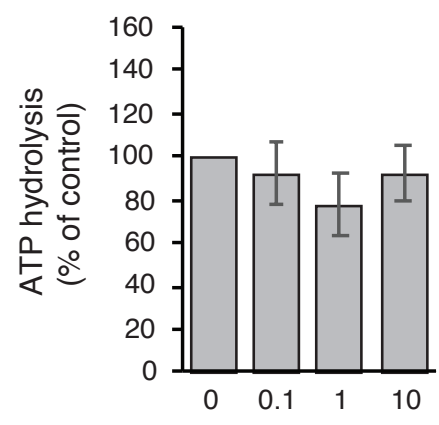

AT7519 $(\mu \mathrm{M})$
B

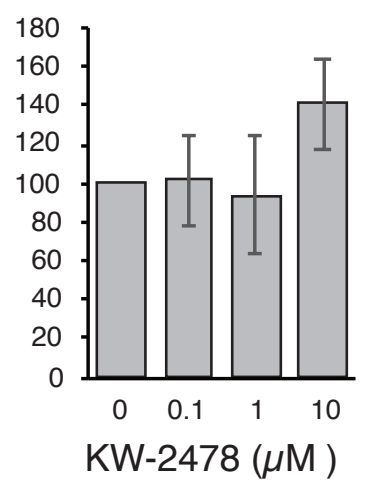

E

Gedatolisib $(\mu \mathrm{M})$

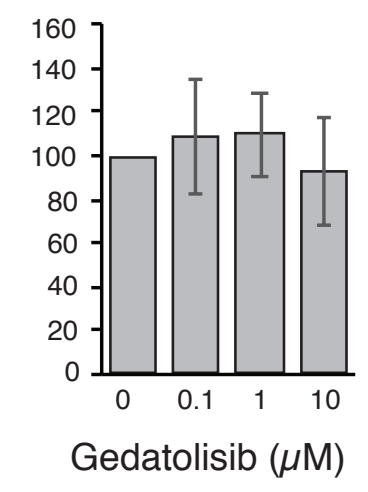

C

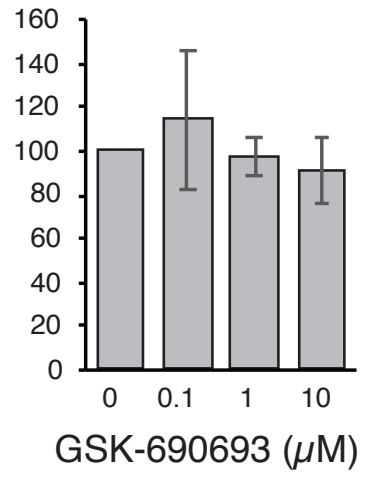


bioRxiv preprint doi: https://doi.org/10.1101/528992; this version posted January 23, 2019. The copyright holder for this preprint (which was not certified by peer review) is the author/funder, who has granted bioRxiv a license to display the preprint in perpetuity. It is made available under aCC-BY 4.0 International license.

Figure 5

A

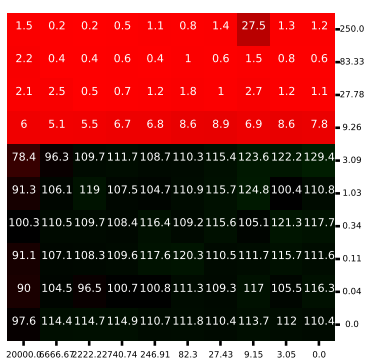

Elacridar (nM)

C

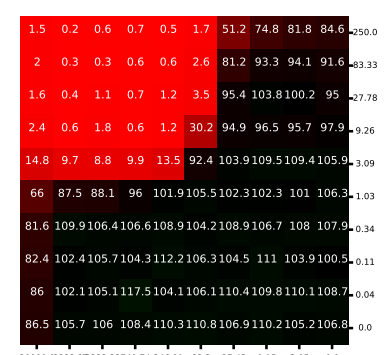

Elacridar (nM)
KB-3-1

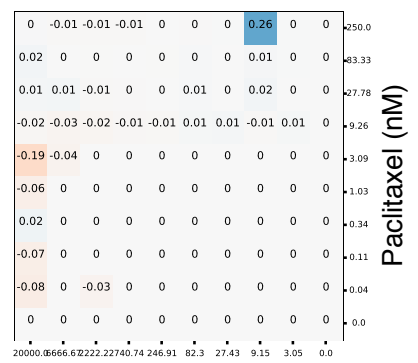

Elacridar (nM)
B

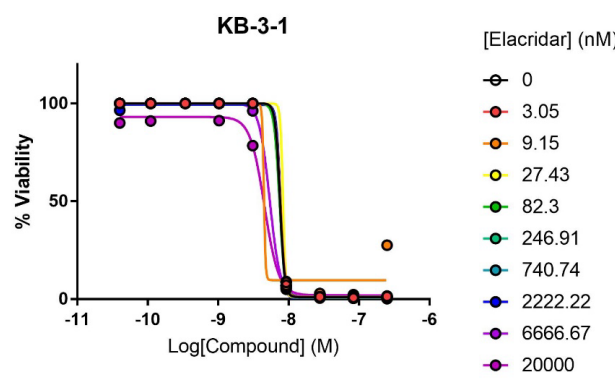

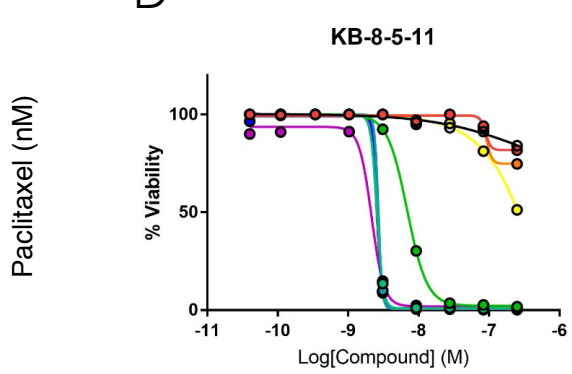

E

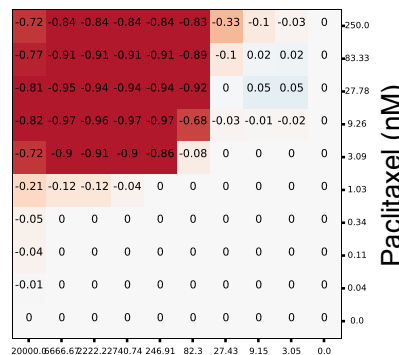

Elacridar (nM)

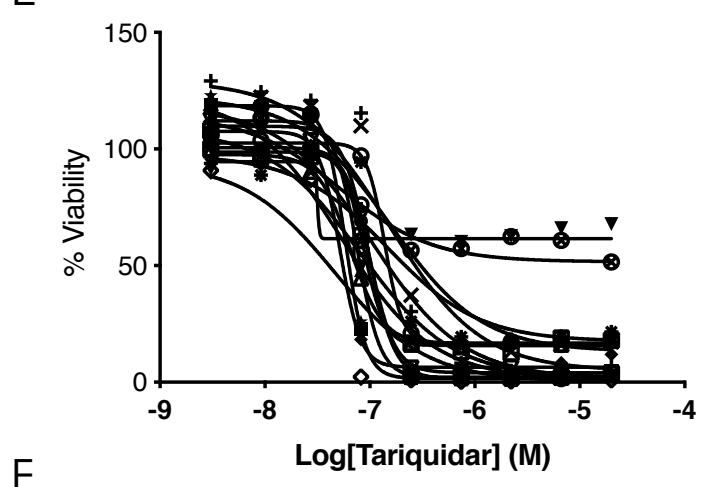

$\rightarrow$ Paclitaxel (-8.03343)

$\rightarrow$ Mithramycin A (-6.6075)

$\rightarrow$ Vinorelbine (-7.5563)

$\rightarrow$ Tozasertib (-5.8293)

$\rightarrow$ Sepantronium bromide (-6.60206)

๑ PKI-587 (-6.60206)

七 PHA-793887 (-5.65321)

$\triangle$ RO495 (-6.03342)

$\rightarrow$ Romidepsin (-7.60745)

F

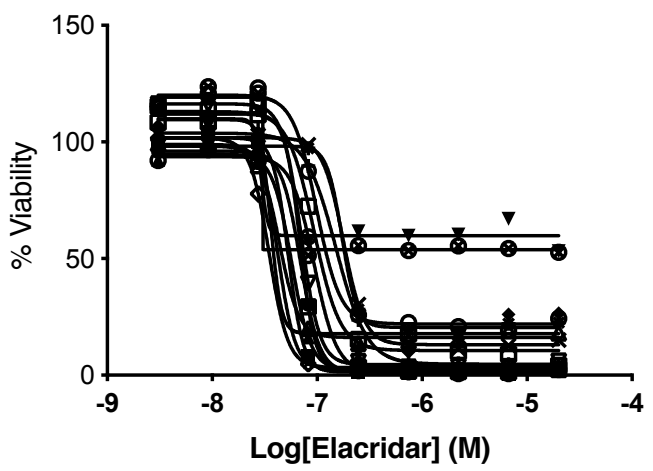

๑ AST-487 (-4.69897)

* PF-05212384 (-6.77815)

* CB 300919 (-8.47711)

+ JNK-IN-7 (-5.65321)

* RA-XII (-7.08462)

- Vinorelbine Tartrate (-6.95424)

七- Docetaxel (-8.35219)

-2 Danusertib (-5.65321) 
bioRxiv preprint doi: https://doi.org/10.1101/528992; this version posted January 23, 2019. The copyright holder for this preprint (which was not certified by peer review) is the author/funder, who has granted bioRxiv a license to display the preprint in perpetuity. It is made available under aCC-BY 4.0 International license.

\section{Figure 6}

A

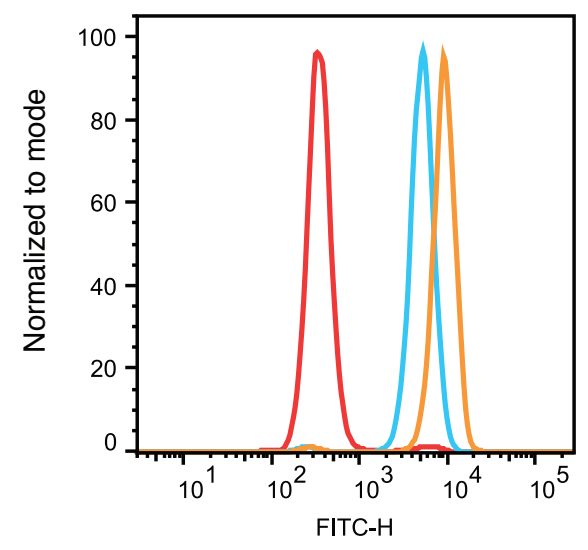

B Pheophorbide a

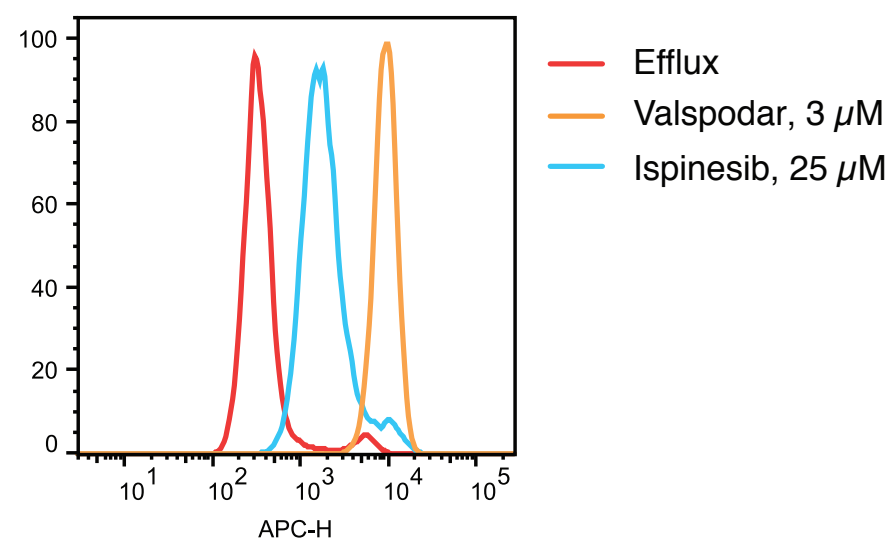

